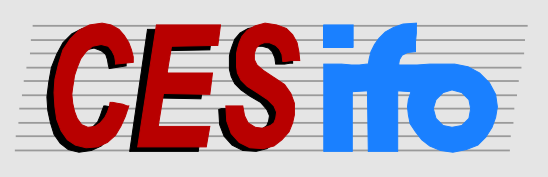

\title{
Working
}

Papers

www.cesifo.org/wp

\section{Dutch Disease in the Post-Soviet Countries of Central and South-West Asia: How Contagious is it?}

\author{
Balázs Égert
}

\author{
CESIFO WORKING PAPER NO. 4186 \\ CATEgory 6: Fiscal Policy, Macroeconomics and GROWTH \\ APRIL 2013
}

An electronic version of the paper may be downloaded

- from the SSRN website:

- from the RePEc website:

- from the CESifo website:

WwW.SSRN.com

www.RePEc.org

www.CESifo-group.org/wp

\section{CESifo}




\title{
Dutch Disease in the Post-Soviet Countries of Central and South-West Asia: How Contagious is it?
}

\begin{abstract}
This study seeks to determine the extent to which the former communist states of Central and South-West Asia are "infected" by the Dutch Disease. We take a detailed look at the functioning of the transmission mechanism of the Dutch Disease, i.e. the chains that run from commodity prices to real output in manufacturing. We complement this with two econometric exercises. First, we estimate nominal and real exchange rate models to see whether commodity prices are correlated with the exchange rate. Second, we run growth equations to analyse the possible effects of commodity prices and the dependency of economic growth on natural resources.
\end{abstract}

JEL-Code: E310, F310, O110, P170.

\author{
Balázs Égert \\ OECD
}

Economics Department

balazs.egert@oecd.org

The views expressed in the paper are those of the author and do not represent the official views of the institutions with which he is affiliated. 


\section{Introduction}

Despite an abundance of, mainly empirical, papers aimed at establishing the extent to which a country's natural resources affects its potential long-term economic growth, there is no wide consensus that countries whose economic structures depend on natural resources are necessarily penalised in the long run with in terms of economic growth.

The seminal paper of Sachs and Werner (1995) and some follow-up research (Collier and Godenis, 2007) argue that the Dutch-Disease effect is a matter of concern for emerging economies in Asia and Sub-Saharian Africa. However, a number of other research papers question the generality of these findings. For instance, Spilimbergo (1999) provides evidence against the Dutch-Disease in commodity-rich Chile and South Africa. Papyrakis and Gerlagh (2004) argue that abundant natural resources do not lower potential growth but rather increase growth in the long run, provided corruption, investment, openness and education are controlled for. Indeed, Kronenberg (2004) points out that corruption is the main obstacle to growth in a set of transition economies. More generally, Gylfason (2001) sets out the preconditions and channels via which natural resources to lead to sluggish long-term economic growth. He shows that (1) illdefined property rights, imperfect or missing markets and lax legal structures, (2) fighting over resource rents and concentration of economic and political power hampering democracy and growth, and (3) the risk of people getting stuck in lowskill intensive natural-resource-based industries comprise the hotbed of the Dutch Disease. This means that strong institutions and a good educational system aimed at upgrading human capital (to enable new and higher value added industries to settle in the country) may help to avoid the Dutch Disease.

Despite the wealth of literature dealing with the Dutch Disease, there are only a few studies that examine specifically the case of the post-soviet countries of Central and South-West Asia. Those that do so focus on specific aspects of the disease. ${ }^{2}$ This paper combines the two strands of the literature. We estimate the influence of changing commodity prices on the nominal and real exchange rates and analyse the extent to which endowment in natural resources influences longrun growth in Central and South-West Asian countries. We test econometrically the channels through which commodity prices may be transmitted to the real economy.

The remainder of the paper proceeds as follows. The next section describes the mechanism via which the Dutch Disease influences the real economy. Section 3 presents some stylised facts. Section 4 studies the relation between oil prices, the exchange rate and economic growth, and Section 5 concludes.

\footnotetext{
${ }^{2}$ For instance, Kronenberg (2004) and IMF (2007) examine long-term growth, and Oomes and Kalcheva (2007), Korhonen and Jurrikkala (2007) and Égert and Leonard (2008) study the effects of developments in oil prices on the exchange rates of Russia and Kazakhstan.
} 


\section{Dutch Disease}

\subsection{The Transmission Mechanism}

In a country that is rich in natural resources, rising commodity prices can ignite a chain of events that may lead to a mighty commodity sector and a deprived manufacturing sector. Rising commodity prices encourage investment in the commodity sector and hence attract labour from the non-commodity sectors. Wages also increase in the commodity sector owing to a labour shortage, which draws labour out of the non-commodity sectors. Corden (1984) labels this the resource movement effect, which results in direct deindustrialization. Indirect deindustrialization happens if the price of non-tradables relative to tradables rises, which draws labour from the manufacturing sector to the non-tradables sector.

There are three theoretical reasons why the relative price of non-tradables may rise. The first is related to the resource movement effect: non-tradables prices rise due to excess demand for them. The demand for non-tradable goods exceeds the supply, as labour leaves the sector.

The second reason that non-tradables prices rise is the increase in nominal and real wages in the commodity sector. If wages tend to equalize across sectors, this leads to higher wages in other sectors of the economy. As a consequence of wage increases in the non-tradable sector (not supported by productivity gains), the relative price of non-tradable goods increases.

Third, the relative price of non-tradables rises to the event that higher profits and wages in the construction sector, and the related tax revenues, are spent on nontradable goods and provided the income elasticity of demand for non-tradables is positive. This third effect is also known the spending effect.

One consequence of the rise in the relative price of non-tradables due to wage spillover from the commodity sector is the appreciation of the real exchange rate. This increase in the relative price of non-tradables may overlap with the traditional Balassa-Samuelson effect due to productivity gains in the non-oil manufacturing sector. If there is proportionate wage equalization across sectors and wage increases feed one-to-one into non-tradables prices, the commodity boom dominates the Balassa-Samuelson effect if wage increases originating in the commodity sector are larger than those in the manufacturing sector that are linked to productivity increases. This appreciation - irrespective of whether it comes from the commodity sector or from the Balassa-Samuelson effect - will not reduce competitiveness so long as the real exchange rate of the manufacturing sector (tradables) remains untouched.

Nonetheless, a real appreciation is possible if the real exchange rate of the manufacturing sector appreciates because of higher wages and prices generated by the wage equalization process from the commodity sector. The effect of wages on prices may be dampened by productivity gains in the manufacturing sector (Balassa-Samuelson effect). An additional source of appreciation of the real exchange rate of the manufacturing sector is the appreciation of the nominal exchange rate due to the inflow of foreign capital, a spin-off from the investment boom in the commodity sector. 
As a consequence of strong appreciation, the manufacturing sector loses competitiveness, manifested as a decline in output and employment, and this leads directly to deindustrialization (Égert and Leonard, 2008). Table 1. below summarizes the symptoms of a construction boom that crowds out the manufacturing sector.

\section{Table 1. Symptoms of a commodity boom}

STAGE

\begin{tabular}{l}
\hline 1. Rise in commodity prices \\
\hline 2. Increase in investment in commodity sector \\
\hline 3. Resource movement effect \\
\hline - changes in real wages in commodity sector \\
- increase (decrease) in employment in commodity (manufacturing, \\
services) \\
\hline 4. Changes in relative price of non-tradables \\
\hline - Resource movement effect \\
- wage equalization: changes in nominal wages in other sectors led by wage \\
rises in commodity sector \\
\hline - spending effect \\
- Balassa-Samuelson effect \\
5. Real exchange rate (RER) \\
4.a. Due to relative price of non-tradables - RER based on the CPI \\
4.b. Due to relative price of tradables - RER based on the PPI \\
4c. Due to nominal appreciation \\
\hline 5. Output and employment declines in manufacturing
\end{tabular}

\subsection{Implications of Dutch Disease for Growth}

As a consequence of nominal and real appreciation driven by commodity prices, the non-commodity manufacturing sector loses competitiveness as manifested in a decline in output and employment. It is precisely the disappearance of the nonoil manufacturing sector which gives rise to boom-bust economic cycles because, during the downturn phase of the commodity price cycle, there is no noncommodity manufacturing to compensate for the decline in commodityproduction. Hence, commodity price fluctuations are strongly reflected in economic fluctuations. This is what we could refer to as the active or long-term Dutch Disease: economic growth is damaged in the long run because noncommodity manufacturing is hollowed out. The Dutch Disease can also be viewed as a structural change caused by a commodity price boom, which reduces diversification and thus exposes the country more to commodity price shocks.

In the short run, even if non-oil manufacturing activity is maintained, economic fluctuations may remain strong due to commodity price fluctuations, simply because of swings in commodity-related activities. The lower the share of the commodity-producing sector in GDP, the smaller the overall economic fluctuations due to the short-term or passive Dutch Disease. 


\section{Stylised Facts}

\subsection{Sectoral Resource Reallocation}

It is interesting to look into the issue of Dutch Disease because the prices of commodities have recorded large increases since the early 2000s. Figure 1 indicates that the nominal price of crude oil rose from slightly over 10 dollars a barrel in 1998 to around 60 dollars in 2006 and above 100 dollars in 2011. This sharp increase may have given rise to the Dutch Disease in economies that rely heavily on extraction and processing of commodities. Post-communist countries in Central and South-West Asia (CSWA) may especially qualify as "commodity economies". According to Figure 2, in 2005, fuel exports accounted for more than $30 \%$ of total exports from Azerbaijan and Kazakhstan. Taking a wider perspective and adding metals, unprocessed foods and agricultural products to fuel exports, reveals that CSWA countries export mostly commodities. The share of commodities in total exports varied between 30\% (Armenia) and about 85\% (Azerbaijan) in 2005. This observation stands in sharp contrast to the considerably lower levels of commodity exports in total exports in other parts of the former Soviet bloc. In Central and Eastern Europe, the Baltic countries and South Eastern Europe, commodities accounted for between 10\% (Czech Republic) and 40\% (Latvia and Lithuania) of total exports in the same year. ${ }^{3}$

A first indication of a possible Dutch Disease is the change in the composition of nominal GDP. Data plotted in Figure 3 shows that the share of the manufacturing sector in total GDP declined systematically between 1990 and 2005, while mining gained more importance over the same period in CSWA countries. Three observations are worthy of note. First, the share of manufacturing fell also in non-CSWA transition economies. It seems that the fall of manufacturing is partly due to the correction of over-industrialisation. Manufacturing generally fell in countries where manufacturing accounted for more than 30\% of total GDP, and it remained stable elsewhere (Czech Republic, Hungary, Lithuania and Slovakia). Second, the share of manufacturing was not strikingly lower in some the CSWA countries than in the comparator group of transition economies not part of the Former Soviet Union (FSU). However, in Armenia, Azerbaijan, Georgia, Kazakhstan, Kyrgyzstan and Mongolia, the share of manufacturing decreased to around or even below 10 percent of GDP. Of these countries, Azerbaijan and Kazakhstan are among the most important fuel exporters. Finally, we can see from the data depicted in Figure 3 that in 2005 the share of mining in GDP amounted to more than $10 \%$ in some of the FSU countries such as Azerbaijan, Kazakhstan, Mongolia and Uzbekistan. By contrast, mining lost importance dramatically in virtually all non-CSWA countries.

\footnotetext{
${ }^{3}$ The large figures for Latvia and Lithuania are due to the fact that much of Russian oil flowed through these countries and because Lithuania has an oil refinery. Thus, the high figures are not a result of oil production.
} 
Figure 1. Nominal crude oil price, 1990-2011

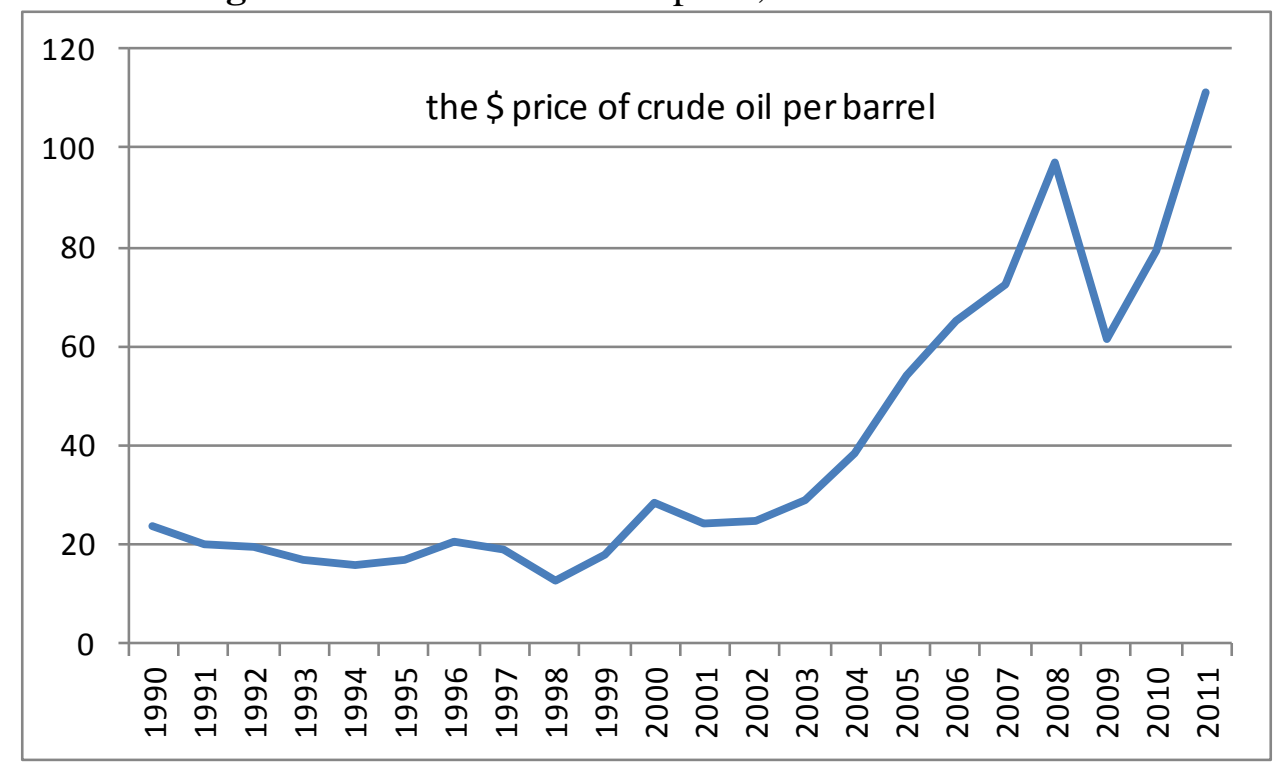

Source: OECD Economic Outlook database

Figure 2. Share of fuel (left) and all commodities in total exports (right), 1996 and 2005

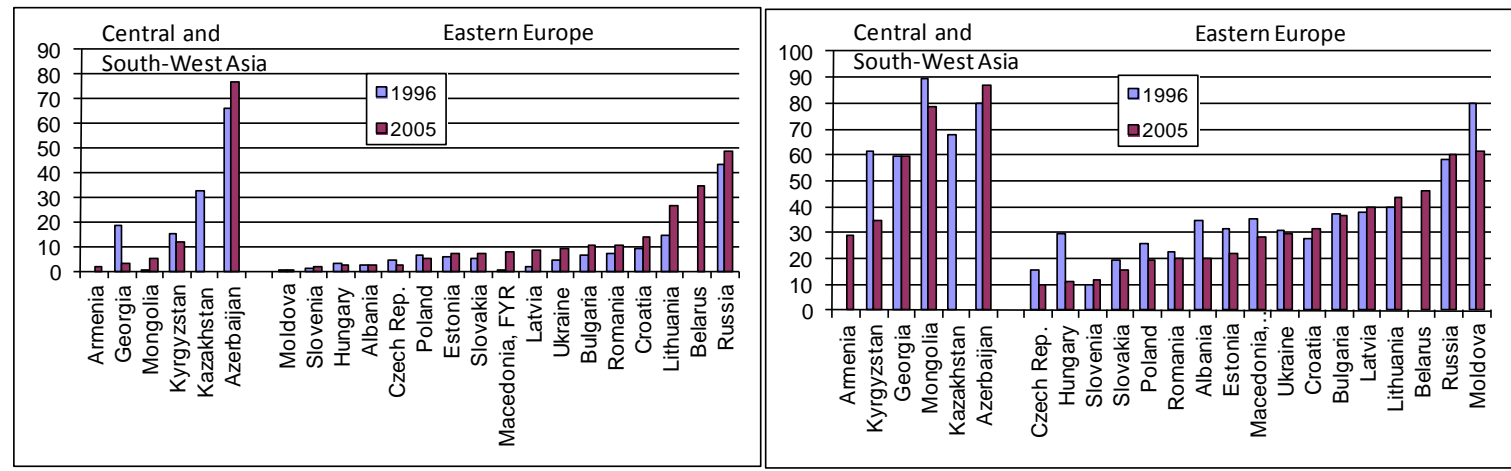

Source: Author's calculations based on data obtained from World Development Indicators database.

Figure 3. Manufacturing (left) and mining (right) as a share of GDP at current prices, 1990-2006

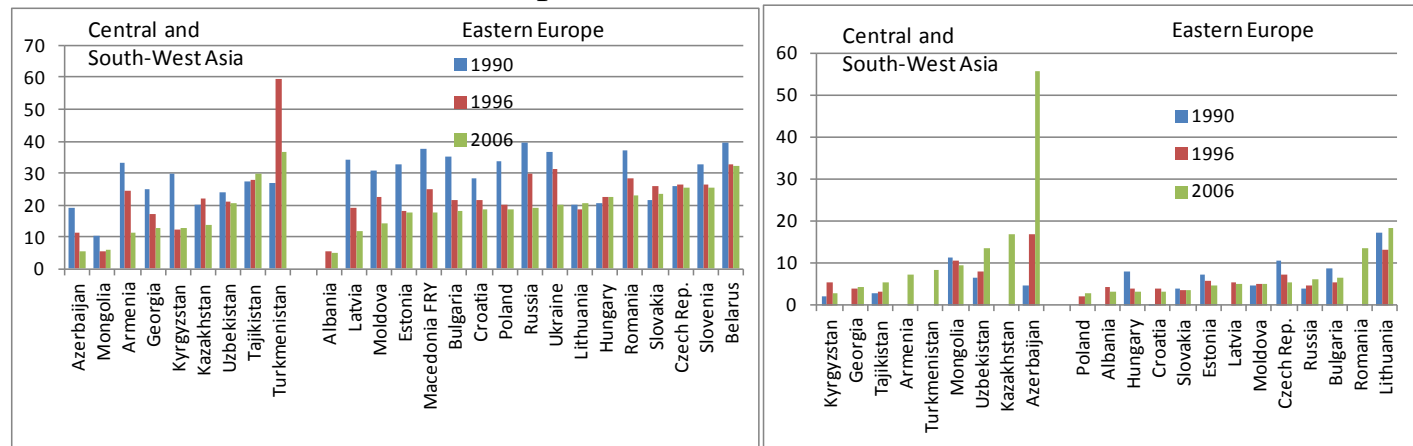

Source: Author's calculations based on data obtained from World Development Indicators database.

We would have liked to look into the issue of a possible movement of labour into the mining sector in the aftermath of oil price increases. But the lack of data on 
sectoral employment that would enable one to distinguish between mining and manufacturing posed a constraint on our analysis. Consequently, we are not able to see the extent to which the rise of commodity prices resulted in a sectoral reallocation of labour to the mining industry from the rest of the economy. There is, however, one studies available to help elucidate the issue for Kazakhstan. Égert and Leonard (2008) use highly disaggregated data to trace the transmission chains of the Dutch Disease. For the period from 1998 to 2005, they do not find robust evidence that oil price increases substantially affected investment and wages in non-oil manufacturing and relative prices in the economy. Their figures suggest that productivity gains in manufacturing largely compensated wage increases over the period studied. Furthermore, they observe little spillover from oil prices to the non-oil prices of the producer price index. Finally, they show that over the same period the real exchange rate of the non-oil tradable sector did not appreciate as a result of oil price increases.

\subsection{Resource Movement, Spending Effect and Relative Prices}

The next chance to catch sight of the elusive Dutch Disease is presented by the study of the impact of the resource movement and spending effects on the relative price of non-tradable goods to that of tradable goods (relative prices). We used two broad measures of relative prices: the ratio of overall CPI to food prices and the ratio of overall CPI to the wholesale price index. Both food prices and the wholesale price index can be viewed as a proxy for tradable goods prices. These measures, despite being not perfect ${ }^{4}$, are widely used in the literature ${ }^{5}$ and allow us to compare broad developments in a relatively large number of countries.

Figure 4 plots average changes in the CPI-PPI ratio and evidence that relative prices declined substantially in CSWA countries for which data are available after $1997 .{ }^{6}$ Relative prices increased more or declined much less in non-CSWA countries during the same period. The annual data series (not plotted in the paper) tell the same story, implying that it is hard to identify - at least based on visual inspection - any correlation between oil prices and the relative price of nontradable goods and casting doubt on the functioning of the resource movement and spending effects.

Let us now turn to the real exchange rate. As figure 5 shows, the real exchange rate calculated on the basis of the CPI and vis-à-vis the dollar appreciated to some extent during the post Russian crisis period, following the large depreciation during and just after the Russian crisis. With the exception of

\footnotetext{
${ }^{4}$ The CPI-to-WPI and CPI-to-food price ratios is not a perfect proxy for the relative price of non-tradable goods to that of tradable goods. First, indirect taxes are included in the calculation of the CPI, but not in the WPI index. Second, the CPI index has a large chunk of regulated/administrative prices, but the WPI and food prices have a lower proportion of regulated prices. Hence, changes in regulated prices have an impact on the ratio. Finally, it is more difficult to adjust for quality changes in services than in goods prices. This may imply an upward pressure on the ratio (Égert, Lommatzsch and Lahrèche-Révil, 2006).

${ }^{5}$ See e.g. MacDonald (1998a,b), Coudert (1999), Rahn (2003) and Égert, MacDonald and Halpern

(2006).

${ }^{6}$ The data are from World Bank’s World Development Indicators database.
} 
Azerbaijan, the real exchange rate of the CSWA countries remained fairly flat after 2001.

Finally, coming to real GDP growth, Figure 6 shows that CSWA countries recorded a much sharper drop in real GDP in the early phase of economic transition, but then they exhibited considerably stronger economic growth rates than their non-FSU counterparts, except for the three Baltic tigers.

Figure 4. Changes in the relative price of non-tradables, 1992-2006

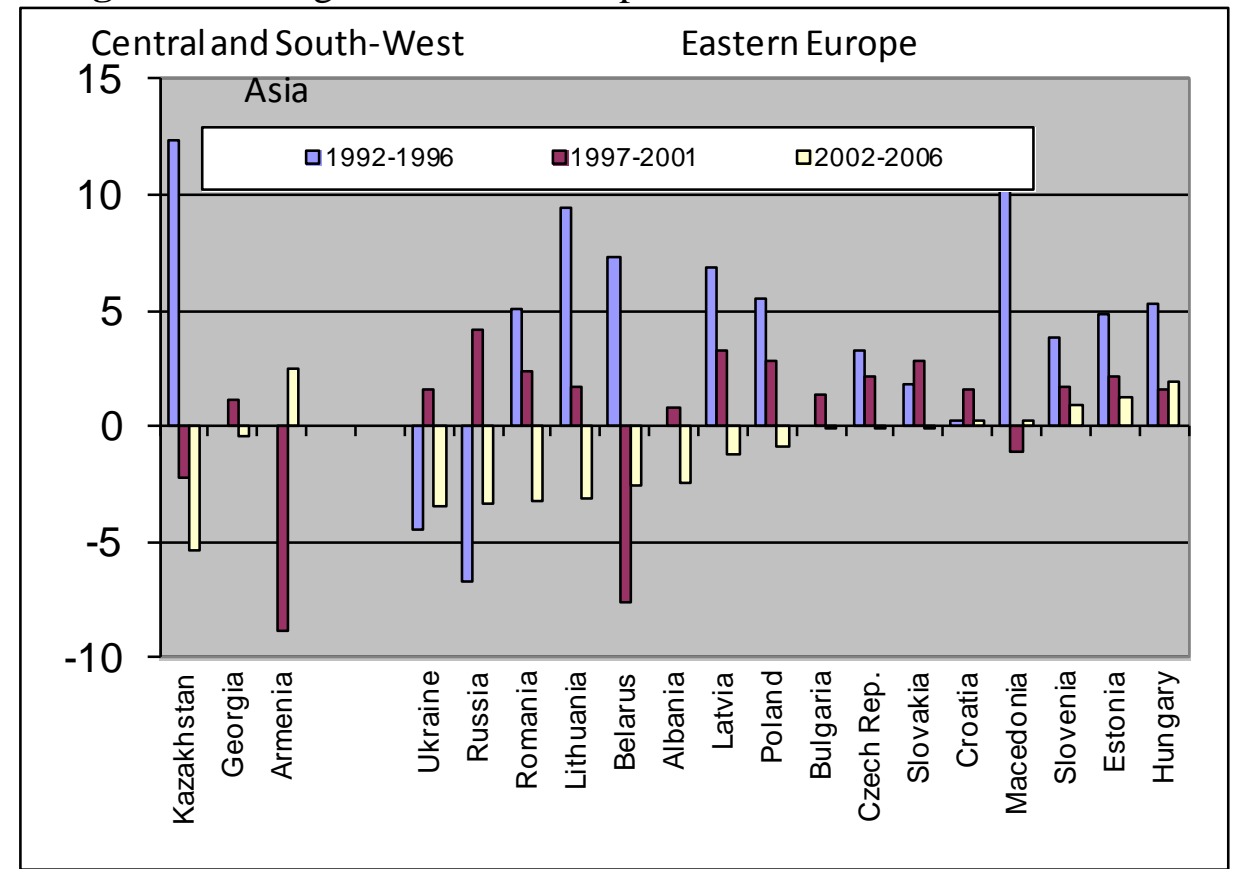

Source: Author's calculations based on data obtained from World Development Indicators database. Relative price is measured as the CPI-to-PPI ratio.

Figure 5. CPI-based real exchange rate vis-à-vis the dollar, 1993-2006, annual changes

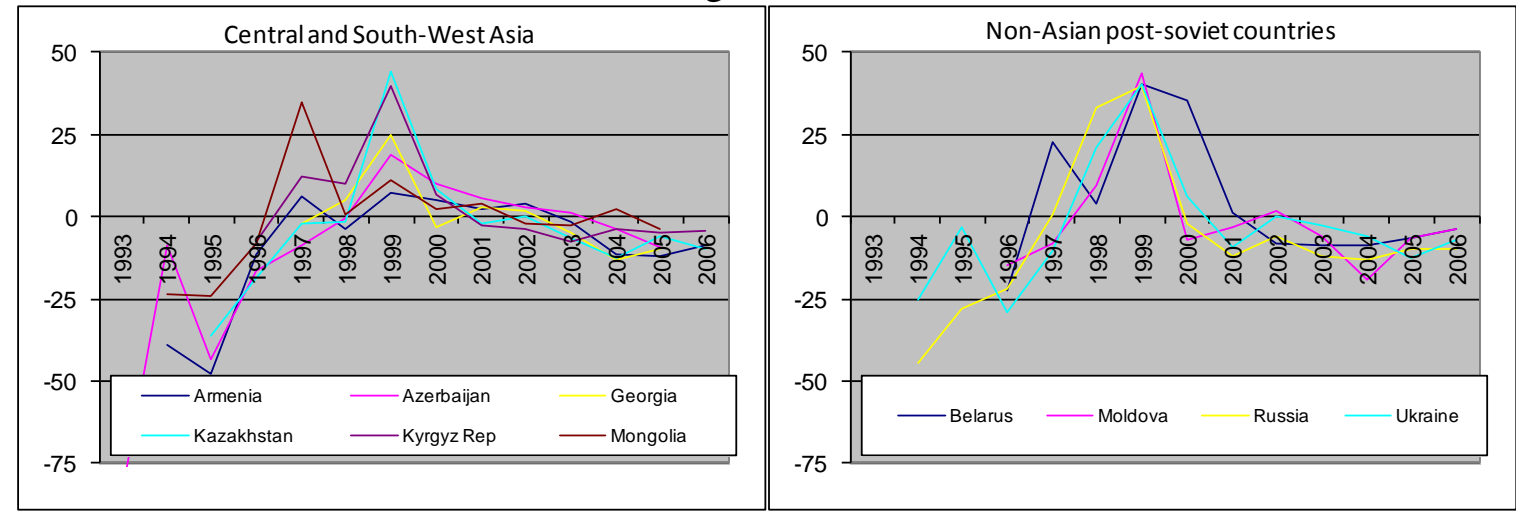

Source: Author's calculations based on data from World Development Indicators database. 
Figure 6. Real GDP growth, 1992-2006

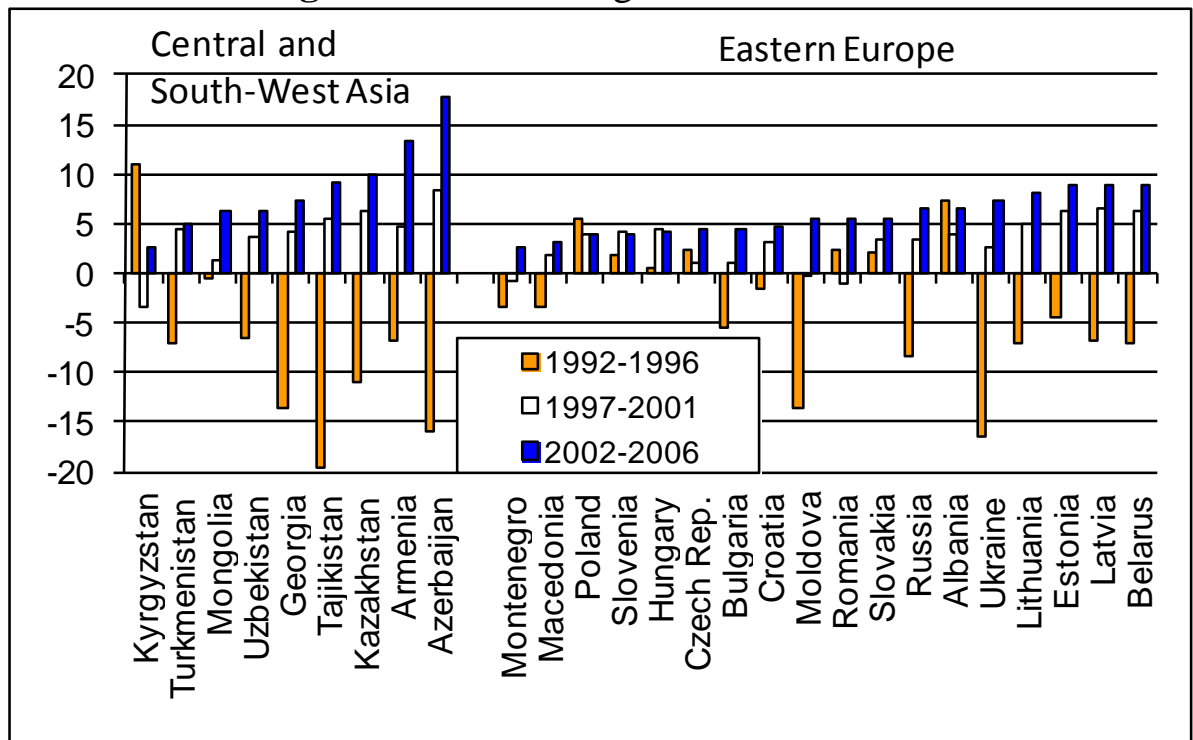

Source: Author's calculations based on data obtained from World Development Indicators database.

\section{Empirical Tests of Dutch Disease}

There are two obvious ways to empirically test for the existence of Dutch Disease. The first relates to the link between developments in nominal and real exchange rates originating from oil prices. The second way is to look at the growth effects of resource abundance and oil prices. We elaborate on these two possibilities in this section.

\subsection{Commodity Prices and the Exchange Rate}

The literature on exchange rate economics provides two straightforward ways to get a grasp on the effect of commodity prices on the exchange rate. First, commodity prices can be incorporated into a standard monetary model of the exchange rate. Second, real commodity prices are a commonly used indicator of terms-of-trade shocks and are used in real exchange rate models. Let us briefly review how commodity prices can be treated in the two approaches.

\subsubsection{Monetary Model and Commodity Prices}

The standard monetary model helps us express the nominal exchange rate as a function of money supply, income and the interest differential between the home and foreign economies:

$e_{t}=m_{t}-m_{t}^{*}-\beta_{1}\left(y_{t}-y_{t}^{*}\right)+\beta_{2}\left(i_{t}-i_{t}^{*}\right)$

where $e_{t}$ is the nominal exchange rate, expressed in units of domestic currency per one unit of foreign currency ${ }^{7}, m_{t}$ and $y_{t}$ are money supply, real income and $i_{t}$ denotes the interest rate, small letters denote - here and in the rest of the paper

\footnotetext{
${ }^{7}$ This implies that an increase (decrease) in the exchange rate is a depreciation (appreciation) of the domestic currency vis-à-vis the foreign currency.
} 
- log-transformed variables, except for interest rates and the asterisk refers to the foreign economy. Equation (1) states that a relative increase in money supply yields a real depreciation, while a rise in relative real income causes a real appreciation. The effect of the interest differential is ambiguous depending on whether short-term or long-term interest rates are used. Higher short-term rates are expected to bring about a real appreciation because via the PPP channel, while an increase in the long-term rate differential is related to a depreciation of the currency, which accords with the uncovered interest parity condition.

It has been shown recently that the failure of the monetary model to explain nominal exchange rate movements in industrialised countries in the 1980s (Meese and Rogoff, 1983) was largely due to the low power of the tests to reject the null of no cointegration between the nominal exchange rate and the monetary fundamentals (MacDonald and Taylor,1994; Groen, 2000; Rapach and Wohar, 2004), the short time span of the data (Rapach and Wohar, 2002) or structural breaks (Goldberg and Frydman, 2001). There is also increasing empirical evidence that the monetary model helps model the exchange rate of some emerging market economies. There has also been mounting evidence that the monetary model perform well for emerging-market economies (see CrespoCuaresma et al., 2005 for emerging European markets, Civcir (2003) for Turkey, Chinn (1999) for East Asian economies and Odedokun (1997) for African countries).

The standard monetary model can be tailored to capture the features of commodity exporting countries. El Shazy (1989) introduces a wealth term in the money demand function of the net oil exporting domestic economy. The wealth term is related to the real value of oil reserves and is expressed as the ratio of the price of oil exports to foreign tradable prices $\left(r p_{t}^{\text {OIL }}=p_{t}^{\text {OIL }}-p_{t}^{*}\right)$ times the expected oil reserves ( $r e s_{t}{ }^{\text {OIL }}$ ). Commodity prices can be added to the money demand function using a similar line of reasoning. Equation (2) below shows the modified monetary model that included real commodity prices:

$e_{t}=m_{t}-m_{t}^{*}-\beta_{1}\left(y_{t}-y_{t}^{*}\right)+\beta_{2}\left(i_{t}-i_{t}^{*}\right)+-\beta_{4} r p_{t}^{\text {COM }}$

One strong assumption of the standard monetary model is that PPP holds for the economy as a whole, i.e. the real exchange rate is stable over time. However, according to the well-known Balassa-Samuelson effect, the real exchange rate may appreciate systematically because of the impact of productivity gains in the tradable sector on the relative price of non-tradables. It can be easily shown that the productivity differential between home and foreign economies can be incorporate into the monetary model as follows:

$e_{t}=m_{t}-m_{t}^{*}-\beta_{1}\left(y_{t}-y_{t}^{*}\right)+\beta_{2}\left(i_{t}^{\text {OUT }}-i_{t}^{\text {OUT* }}\right)-(1-\phi)\left(\left(a_{t}^{T}-a_{t}^{N T}\right)-\left(a_{t}^{T *}-a_{t}^{N T^{*}}\right)\right)$

where $a_{t}^{N T}$ and $a_{t}^{T}$ are productivity in the non-tradable and tradable sectors (see e.g. Crespo-Cuaresma, Fidrmuc and MacDonald, 2005). This upward trend in goods prices in the home country can be captured by the introduction of a trend term in the money demand function of the home economy, which gives us the modified exchange rate equation as in equation (4): 
$e_{t}=m_{t}-m_{t}^{*}-\beta_{1}\left(y_{t}-y_{t}^{*}\right)+\beta_{2}\left(i_{t}-i_{t}^{*}\right)-\beta_{4}$ trend

\subsubsection{Real Exchange Rate and Commodity Prices}

The risk-adjusted real interest parity relationship, which has been used extensively in the literature (see e.g. Faruqee, 1995; MacDonald, 1998a,b), provides a convenient framework for modelling the relationship between the real exchange rate and economic fundamentals. The real interest parity condition states that the real exchange rate expected one period ahead is a function of the expected real interest rate and a the time-varying risk premium. If the expected real exchange rate is the outcome of the expected values of the economic fundamentals, the observed real exchange rate is determined by the vector of long-run fundamentals assuming rational expectations.

Real commodity prices are commonly included in real exchange rate models to capture terms-of-trade fluctuations. In net commodity exporting countries, an increase in commodity prices relative to the price of other (imported) goods represents a positive terms-of-trade shock and thus leads to real appreciation, whereas higher commodity prices generate a negative terms-of-trade shock in net commodity importing countries and causes the real exchange rate to depreciate.

Of the many other potential fundamentals, the productivity variable is by far the most robust for most empirical work. Productivity affects the real exchange rate via two channels. The first is the Balassa-Samuelson effect, which transits through the relative price of non-tradables versus tradables. The second channel concerns the real exchange rate of the tradables sector. According to New Open Economy Macroeconomics (NOEM) models, productivity gains in the tradables sector causes the real exchange rate of that sector to depreciate through the termsof-trade channel (see e.g. MacDonald and Ricci, 2002 and Benigno and Thoenissen, 2003). Whether or not the real exchange rate of the whole economy depreciates or appreciates in the aftermath of an increase in productivity of the tradables sector depends on whether the depreciation of the open sector's real exchange rate is outweighed by the real appreciation induced by the BalassaSamuelson effect.

By contrast, productivity gains in tradables can cause a real appreciation of the tradable sector's exchange rate due to quality effects on both on the production and consumption side. On the one hand, the catching-up process entails the production of goods and services of improved quality. On the other hand, private households grow richer and upgrade the quality of their consumption basket, which can be viewed as an extension of Engel's law. To the extent that these changes occur rapidly, statistical agencies may find it difficult to filter out all quality effects from the inflation rates. As a result, quality effects will, to varying degrees, show up in inflation rates (Égert, Lommatzsch and Lahrèche, 2006 and, for formal modelling, Bruha and Podpiera, 2007). Égert, Lommatzsch and Lahrèche (2006) provide ample empirical evidence on how differently productivity gains impact the real exchange rate of mature OECD economies and catching-up transition economies.

It has been argued recently that remittances may play an important role in real exchange rate movements in developing countries. Lopez, Molina and Bussolo (2007) argue that workers' remittances can influence the exchange rate because 
they are reflected in capital inflows. They identify three channels through which remittances may impact the exchange: via net foreign effects, via demand effects on services if remittances are spent on consumption rather than on investment and via economic growth. Our country sample includes a number of countries where remittances are fairly large. It is against this background that we also use remittances as an explanatory variable.

Figure 7. Remittances as a share of GDP, 2000-2006

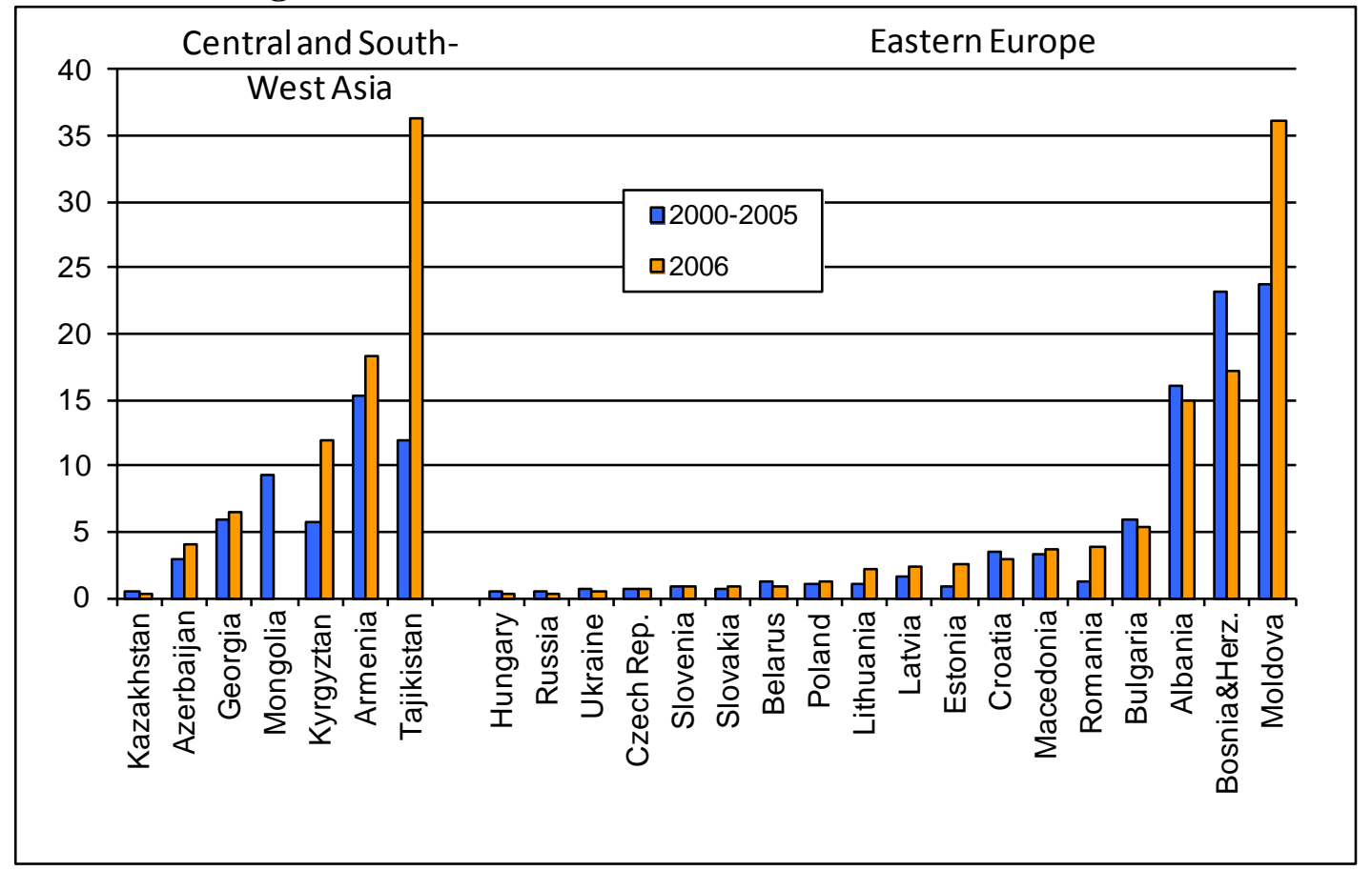

Source: Author's calculations based on data from World Development Indicators database.

\subsubsection{Testable equations}

We estimate three variants of the monetary model sketched above:

1. Standard monetary model augmented with commodity prices

2. Balassa-Samuelson monetary model augmented with commodity prices

3. Monetary model augmented with a trend and commodity prices

We do not include the interest rate variable in the monetary model because, according to the EBRD's transition indicators, the financial sector, measured by the "banking reform \& interest rate liberalization" and the "securities markets \& non-bank financial institutions" indicators is largely under-developed in FSU countries, inducing a low responsiveness of the interest rate.

For the real exchange rate, we estimate a model for the CPI-based real exchange rate that includes GDP per capita vis-à-vis the foreign benchmark and real commodity prices. The choice of the per-capita income variable is motivated by the fact that sectoral productivity figures that allow for separation of commodity and non-commodity productivity are not available for our set of countries. It needs to be emphasized that the per-capita income variable not only captures the Balassa-Samuelson effect but is also a proxy for factors driving the appreciation 
of the tradables sector's real exchange rate. Furthermore, this variable can also reflect demand-side effects. Finally, remittances as a share of GDP will be also used in the estimations. As result, the following reduced-form equations are estimated for the real exchange rate:

1. Real exchange rate, GDP per capita and real oil prices

2. Real exchange rate, remittances and real oil prices

3. Real exchange rate, GDP per capita, remittances and real oil prices

\subsubsection{Estimation results}

We first use standard panel unit root tests to analyse the time series properties of our data. ${ }^{8}$ The Levin-Lin-Chu (LLC) test, which imposes homogenous mean reversion on the sample, and the Im-Pesaran-Shin (IPS) test, which allows for country specific mean reversion, suggest that most of the series used with the nominal and real exchange rate models are stationary. The nominal and real exchange rate series also turn out to be stationary in levels. By contrast, both tests indicate that the nominal and real oil price series have a unit root. Additionally, there is some mixed evidence for some of the other explanatory variables, such as GDP per capita, real GDP and monetary aggregates. This leads us to use logdifferenced series because differencing the data transforms the independent variable of interest (oil prices) into a stationary series. In this way we can obtain economically meaningful coefficients by regressing changes in the exchange rate on changes in the price of oil.

Tables 2 and 3 report estimation results obtained for the dollar and euro exchange rates. The estimations are carried out for a panel including the group of CSWA countries and European post-soviet countries. We combine these countries in a single group of FSU countries to increase the data points and because these countries can be thought of as having comparable economic structures because of their common past.

We carried out the estimation for the whole period, from 1991 to 2006. Because there is an obvious break in the exchange rate series of the FSU countries around the time of the Russian crisis (see Figure 5), we split the sample in two subsamples. Only results obtained for the sub-period from 1999 to 2006 are reported in Tables 2 and 3, as the results for the whole period and the first subsamples do not seem to provide any additional information regarding exchange rate movements in the FSU countries.

We first carried out a simple bivariate regression between the nominal exchange rate and nominal oil prices on the one hand, and the real exchange rate and the real price of oil (deflated by US CPI). The striking finding is that there seems to be no statistical relationship between changes in the exchange rate and changes in oil prices. The fixed-effect OLS estimations for the monetary model and variants of the real exchange rate model do not alter this conclusion.

The lack of statistical relationship between oil prices and the exchange rate may be due to several factors. First, our sample period might be too short to detect

\footnotetext{
${ }^{8}$ The following data series are calculated as the ratio of the domestic variable to the foreign benchmark (USA or euro area): monetary aggregates, real GDP growth and GDP per capita (in PPS).
} 
such a relationship. Second, countries may be affected differently, so that those that are influenced less by oil prices dominated those for which oil prices would matter for exchange rate movements. Finally, the oil price may feed into an appreciation with some lag. We check this latter possibility by employing lagged nominal and real oil prices. The bivariate relationships suggest that changes in the nominal oil price influence the nominal exchange rate of FSU countries against the dollar after a lag of one or two years. For the euro exchange rates, even the contemporaneous coefficient becomes significant. Nevertheless, once we account for the determinants of the monetary model, only the nominal oil price lagged by one year remains statistically significant for the dollar exchange rate. The effects of oil prices be virtually unchanged by the inclusion of the monetary variables.

We observe a similar pattern for real oil prices and the real exchange rate: the real price of oil induces a real appreciation after a lag of one or two years. The inclusion of the other control variables does not change the results. ${ }^{9}$

Table 2. Monetary model

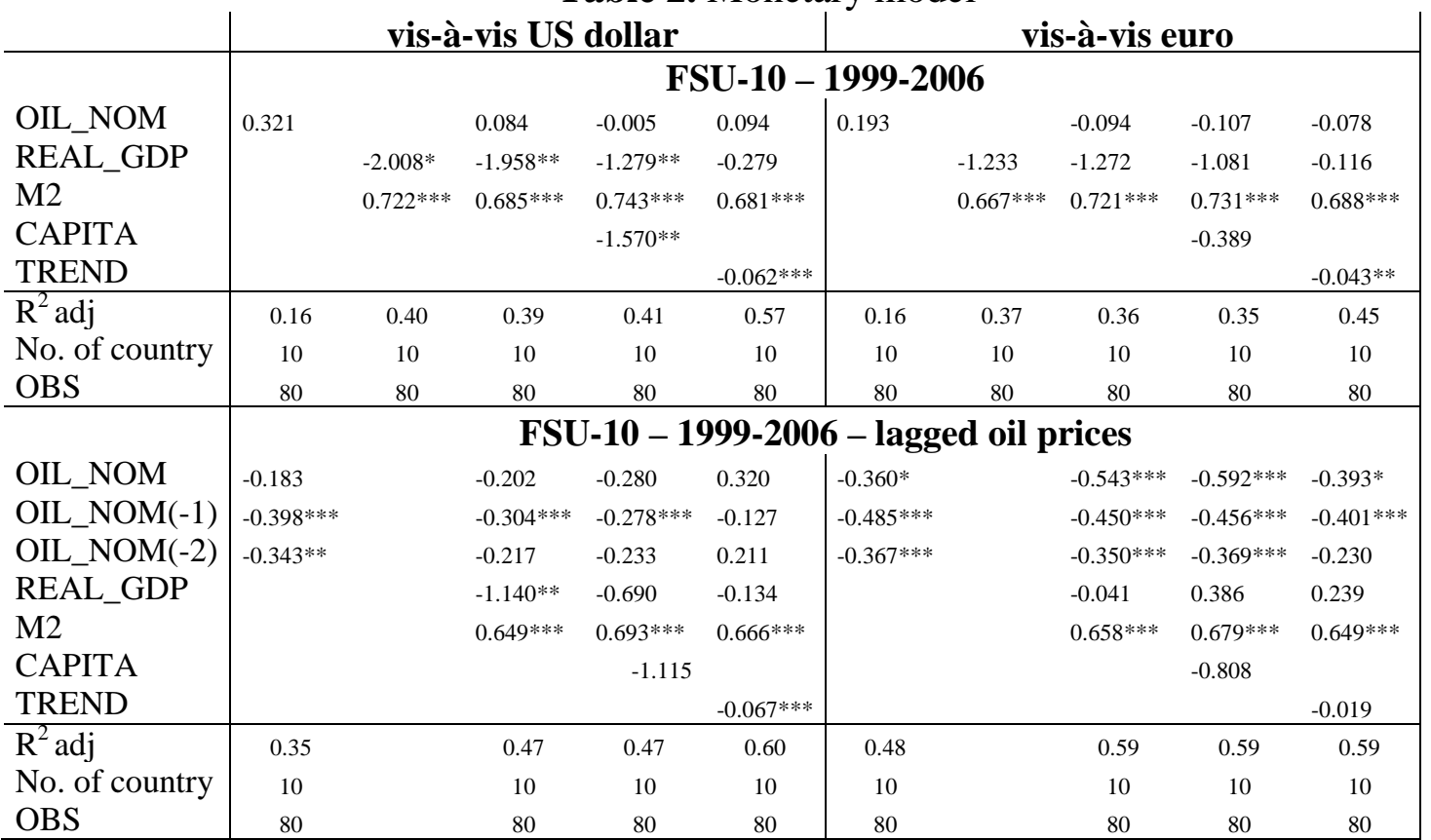

Notes: $*, * *$ and $* * *$ indicate statistical significance at 10, 5 and 1 percent levels.

\begin{abstract}
${ }^{9}$ Regarding the monetary model, its standard version appears to produce the expected results for the FSU countries against the US dollar and for the non-FSU countries against the US dollar and euro: relative real GDP growth causes the nominal exchange rate to appreciate while relative money supply generates a currency depreciation. Relative GDP per capita and the time trend are also found to lead to nominal appreciation. This result is less robust, partly because the issue of multi-collinearity may arise between the relative GDP per capita and relative real GDP variables. The adjusted R-square for the monetary model suggests that about a half of the variation in the nominal exchange rate can be explained by the explanatory variables.
\end{abstract}

Turning now to the real exchange rate models, it is noteworthy that relative GDP per capita growth and remittances are associated with an appreciation of the dollar real exchange rate of FSU countries. For the euro exchange rate, none of the variables are statistically significant. Interestingly, and contrary to earlier findings of the literature, the real exchange rate models perform quite poorly for non-FSU countries. 
Table 3. Real exchange rate models

\begin{tabular}{|c|c|c|c|c|c|c|c|c|}
\hline \multirow{5}{*}{$\begin{array}{l}\text { OIL_REAL } \\
\text { CAPITA } \\
\text { REMITTANCES }\end{array}$} & \multicolumn{4}{|c|}{ vis-à-vis US dollar } & \multicolumn{4}{|c|}{ vis-à-vis euro } \\
\hline & \multicolumn{8}{|c|}{ FSU-10 - 1999- 2006} \\
\hline & 0.148 & 0.019 & 0.131 & 0.022 & 0.004 & -0.012 & 0.002 & -0.010 \\
\hline & & $-1.916^{* *}$ & & $-1.702 * *$ & & -0.363 & & -0.296 \\
\hline & & & $-0.065 * * *$ & $-0.043 * * *$ & & & -0.014 & -0.009 \\
\hline $\mathrm{R}^{2}$ adj & -0.05 & 0.18 & 0.04 & 0.21 & -0.11 & -0.12 & -0.12 & -0.13 \\
\hline No. of country & 10 & 10 & 10 & 10 & 10 & 10 & 10 & 10 \\
\hline \multirow[t]{2}{*}{ OBS } & 77 & 77 & 76 & 76 & 77 & 77 & 76 & 76 \\
\hline & \multicolumn{8}{|c|}{ FSU-10 - 1999- 2006 lagged real oil prices } \\
\hline OIL_REAL & -0.143 & $-0.193^{*}$ & -0.113 & -0.170 & $-0.333^{* * *}$ & $-0.329 * * *$ & $-0.364 * * *$ & $-0.359^{* * *}$ \\
\hline OIL_REAL(-1) & $-0.256^{* * *}$ & $-0.205^{* * *}$ & $-0.245^{* * *}$ & $-0.203 * * *$ & $-0.350 * * *$ & $-0.355^{* * *}$ & $-0.359 * * *$ & $-0.361 * * *$ \\
\hline OIL_REAL(-2) & $-0.192 * * *$ & $-0.177^{* *}$ & $-0.158^{* *}$ & $-0.157 * *$ & $-0.212 * * *$ & $-0.216^{* * *}$ & $-0.239 * * *$ & $-0.239 * * *$ \\
\hline CAPITA & & $-1.187^{* * *}$ & & $-1.060 * *$ & & 0.230 & & 0.130 \\
\hline REMITTANCES & & & $-0.042 * *$ & -0.031 & & & 0.020 & 0.018 \\
\hline $\mathrm{R}^{2}$ adj & 0.32 & 0.39 & 0.35 & 0.41 & 0.65 & 0.65 & 0.65 & 0.65 \\
\hline No. of country & 10 & 10 & 10 & 10 & 10 & 10 & 10 & 10 \\
\hline OBS & 77 & 77 & 76 & 76 & 77 & 77 & 76 & 76 \\
\hline
\end{tabular}

Notes: $*, * *$ and $* * *$ indicate statistical significance at the 10,5 and 1 percent levels.

\section{Natural Resources and Economic Growth}

\section{1. The Setup}

The next question relates to the impact of resource abundance and commodity prices on economic growth. We argued earlier that commodity prices may correlate positively with economic growth in the short run (passive Dutch Disease) and that the presence of important natural resources could impede economic growth in the longer run (active Dutch Disease).

To probe these matters, we estimate growth equations to determine the extent to which the reliance on natural resources influences long-term economic growth. We use several proxies:

- $\quad$ the share of fuel exports in total exports (X_OIL)

- the share of natural resources (fuel, metal, agricultural products and food) in total exports (X_NATRES)

- $\quad$ the share of the mining industry in total GDP (MINING)

The theoretical underpinning of growth equations is the production function approach, which decomposes output per capita into i.) TFP, ii.) (physical and human) capital, , and iii.) labour input. Growth equations include either the direct determinnants of growth, or policy and institutional variables, which influence the growth determinants. We incorporate the control variables used in the growth literature. While there seems to be no consensus on what the usual determinants of long-term growth are (see e.g. Durlauf et al, 2004 and Barro and Sala-i-Martin, 2004), we employ the main factors commonly viewed as drivers of economic growth in our benchmark specification:

- investment-GDP ratio (INV)

- government consumption-GDP ratio (GOVC) 
- labour force growth rate (LABFOR)

- openness (ratio of exports + imports of goods and services to GDP, OPEN)

- human capital measured by educational attainment: total upper secondary education enrolment (EDU1), higher education enrolments (gross ratios, percent of population aged 19-24) (EDU2) and Public expenditure on education (percent of GDP) (EDU3)

- health of the population in 1990 measured by Public sector expenditure on health (percent of GDP) (HEALTH1) and incidence of tuberculosis (new cases per 100000 population) (HEALTH2)

In transition economies, initial conditions are particularly important, especially in the early days of transition. We employ the following variables for initial conditions that could impact economic growth:

- level of GDP per capita in 1990 (CAPITA90)

- $\quad$ human capital in 1992: total upper secondary education enrolment in 1992 (EDU1_92) and higher education enrolments in 1992 (EDU_92)

- health of the population in 1990, measured by incidence of tuberculosis (HEALTH2_90)

- foreign debt as a share of GDP in 1993 (FDEBT_93)

It should be noted that initial conditions can be used as constant terms given that they take the same value over time. As a result, only one of them can be included at a time.

We include another set of variables viewed as crucial for transition and developing economies:

- inflation as a measure of macroeconomic stability (INF)

- corruption, measured by two indicators: corruption index of Transparency International (CORR_TI) in 1999 and corruption index for 2002 published by World Bank (\% of managers surveyed ranking this as a major constraint) (CORR_WB)

- additionally, we interact corruption with natural resources.

- structural indicators reflecting reforms implemented in the corporate and banking sectors (INSTIT)

- remittances as a share of GDP (REMIT)

We take a long-term perspective and perform cross-sectional regressions using 5year and 8-year averages of the dependent and independent variables. We have three observations for each country when 5-year averages are used (1992-1996, 1997-2001, 2002-2006) and two observations for 8-year averages (19911998,1999-2006).

Our sample contains the CSWA countries, the European post-soviet countries and transition countries from Central and Eastern Europe to ensure sufficient variability in the share of oil production/natural resources in GDP. 
While the growth literature usually suggests regressing the growth rate of GDP per capita in PPP on the above set of variables, we will also use real GDP growth rates, being an indicator of utmost policy interest.

\section{1. Estimation Results}

Table 4a below reports the results of the bivariate relationship between real GDP growth (or the growth rate of per capita income in PPS) and the three measures capturing natural resource abundance. The amount of oil exports in total exports and the relative size of the mining industry turn out to be correlated positively with growth. The relationship is, however, not significant when the share of all primary goods (oil, metal, agricultural products and foodstuff) in total exports is included. This suggests that positive growth effects are due to flourishing oil exports and the mining industry, but not to the other (mainly agricultural) sectors.

The question that arises is whether the relation between oil production and exports increased over time, in particular with the observed increase in crude oil prices over the last 10 years or so. To answer this question, we interacted the three measures at hand with a time trend. The results show that the effect of natural resources on economic growth increased over time, irrespective whether 5-year or 8-year averages were used.

Next, we added a set of control variables to the growth equation estimated with fixed effect OLS. Table 4b reports the results for GDP per capita growth, which shed light on the relation between oil exports and growth. We find a negative relation between oil exports and growth. Nonetheless, oil exports interacted with a time trend are found to increase long-term growth. Our interpretation of these results is that during the first stage of transition, the reliance on oil production did not facilitate economic growth, but it started to contribute to growth from the mid-1990s. This is fairly intuitive if we think of the pronounced declines in GDP in the major oil producing transition economies during the first half of the 1990s and the robust growth these countries have experienced since then, compared to the non-oil producing transition economies.

It is noteworthy that high inflation rates reduce long-term growth, whereas an increase in the labour force and higher remittances increase growth for our set of countries. The other controls remain statistically insignificant.

Finally, we used the two measures of corruption (for each of which we have just one observation per country) and a number of variables aimed at controlling for initial conditions. Because these variables act as country-specific effects, we carried out pooled OLS including a constant term. Our previous findings seem to be very robust to the inclusion of initial conditions. In fact, the initial conditions and the degree of corruption are unimportant for economic growth, at least for our country sample. 
Table 4a. Growth equations - Bivariate relationships

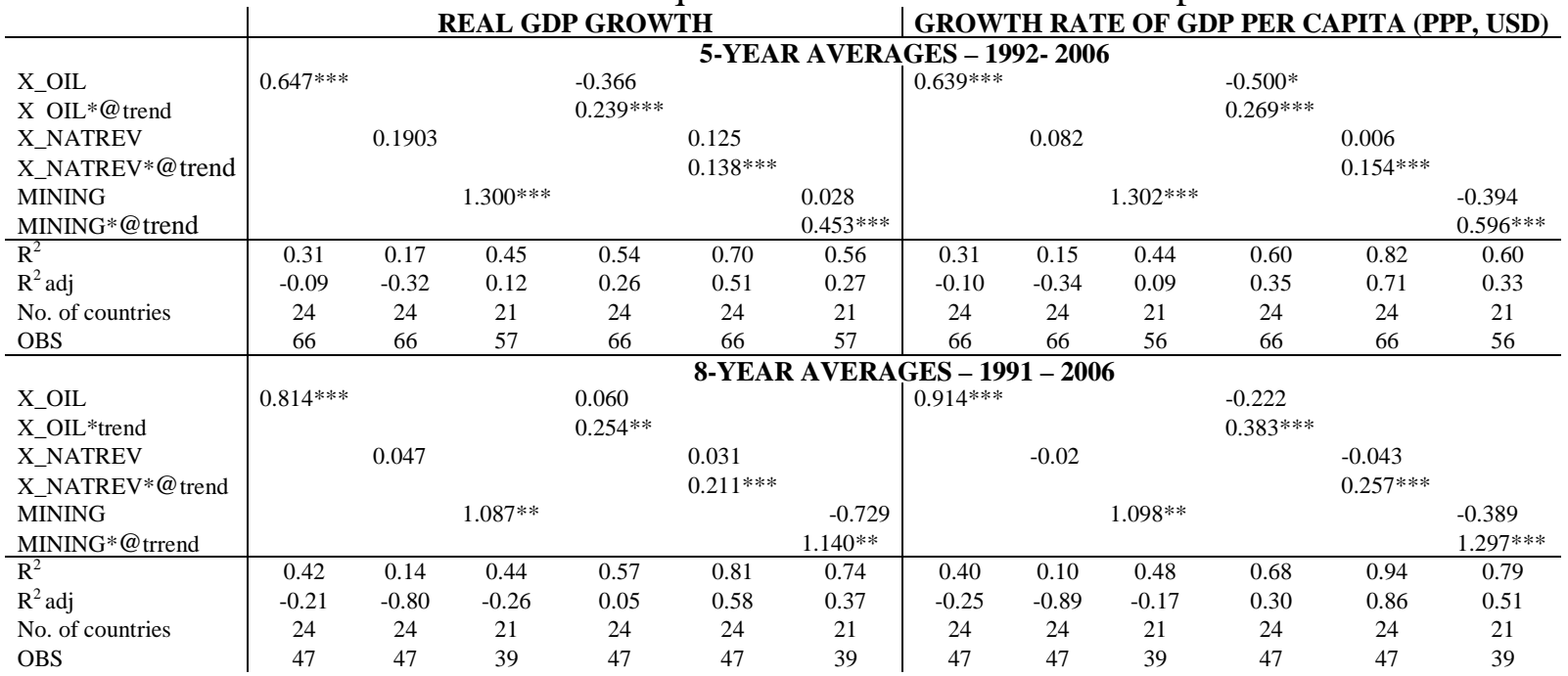

Note: $* * *$ and $* * *$ indicate statistical significance at 10,5 and $1 \%$ levels.

Table 4b. Growth equations

GROWTH RATE OF GDP PER CAPITA (PPP, USD)

5-YEAR AVERAGES 8-YEAR AVERAGES 1992-2006 1991-2006

\begin{tabular}{|c|c|c|c|c|c|c|}
\hline & \multicolumn{3}{|c|}{ 1992-2006 } & \multicolumn{3}{|c|}{ 1991-2006 } \\
\hline X_OIL & $-0.463^{* *}$ & $-0.426 * *$ & $-0.435^{* *}$ & $-0.509 * *$ & $-0.481 * *$ & $-0.442 *$ \\
\hline X_OIL*@TREND & $0.137 * * *$ & $0.135 * * *$ & $0.123^{* * *}$ & $0.269 * * *$ & $0.269 * * *$ & $0.253^{* *}$ \\
\hline CPI & $-0.011^{* * *}$ & $-0.011 * * *$ & $-0.011^{* * *}$ & $-0.010^{* * *}$ & $-0.010^{* * *}$ & $-0.009 * *$ \\
\hline OPEN & -0.033 & -0.033 & -0.055 & 0.061 & 0.071 & 0.069 \\
\hline GOVC & 0.192 & 0.217 & 0.169 & 0.106 & 0.376 & 0.207 \\
\hline INV & -0.097 & -0.074 & -0.084 & 0.220 & 0.240 & 0.197 \\
\hline INSTIT & 2.754 & 2.197 & $4.999 * *$ & -0.635 & -0.116 & 2.924 \\
\hline LABFOR & $1.739 * *$ & $1.594^{* *}$ & $1.361^{*}$ & 0.077 & 0.131 & 0.140 \\
\hline REMIT & $0.650^{* * *}$ & $0.659 * * *$ & $0.611^{* * *}$ & $0.698 * *$ & $0.675^{* *}$ & $0.679 *$ \\
\hline EDU1 & 0.057 & & & 0.222 & & \\
\hline EDU2 & & 0.054 & & & 0.087 & \\
\hline EDU3 & & & -0.772 & & & 0.661 \\
\hline HEALTH2 & 0.070 & 0.060 & 0.053 & $0.126 * *$ & $0.086 *$ & 0.093 \\
\hline $\mathrm{R}^{2}$ & 0.90 & 0.90 & 0.91 & 0.96 & 0.96 & 0.95 \\
\hline $\mathrm{R}^{2}$ adj & 0.80 & 0.80 & 0.81 & 0.83 & 0.84 & 0.81 \\
\hline No. of countries & 22 & 22 & 22 & 22 & 22 & 22 \\
\hline OBS & 63 & 63 & 61 & 44 & 44 & 43 \\
\hline
\end{tabular}

Note: ${ }^{*}, * *$ and $* * *$ indicate statistical significance at 10,5 and $1 \%$ levels. 
Table 4c. Growth equations - initial conditions, 5-year averages GROWTH RATE OF GDP PER CAPITA (PPP, USD)

\begin{tabular}{|c|c|c|c|c|c|c|c|}
\hline \\
\hline X_OIL & $-0.094 *$ & $-0.095^{*}$ & $-0.110 *$ & $-0.094 *$ & $-0.096 *$ & $-0.092 *$ & $-0.117 * *$ \\
\hline X_OIL*@trend & $0.120 * * *$ & $0.121 * * *$ & $0.127 * * *$ & $0.117 * * *$ & $0.122 * * *$ & $0.121 * * *$ & $0.125 * * *$ \\
\hline CPI & $-0.009 * * *$ & $-0.009 * * *$ & $-0.009 * * *$ & $-0.008 * * *$ & $-0.009 * * *$ & $-0.009 * * *$ & $-0.009 * * *$ \\
\hline OPEN & 0.000 & -0.002 & 0.000 & -0.010 & 0.000 & -0.001 & -0.009 \\
\hline GOVC & -0.314 & -0.321 & -0.176 & -0.247 & -0.290 & -0.287 & -0.262 \\
\hline INV & 0.126 & 0.115 & 0.123 & 0.112 & 0.135 & 0.132 & 0.142 \\
\hline INSTIT & 0.208 & 0.276 & 0.244 & 0.220 & 0.400 & 0.350 & 0.262 \\
\hline LABFOR & 0.095 & 0.092 & 0.140 & 0.357 & 0.016 & 0.037 & 0.134 \\
\hline REMIT & $0.428 * * *$ & $0.414^{* * *}$ & $0.405^{* * *}$ & $0.387 * * *$ & $0.410 * * *$ & $0.406 * * *$ & $0.439 * * *$ \\
\hline EDU1 & $0.143^{* *}$ & $0.164 * *$ & $0.159 * *$ & $0.165^{* * *}$ & $0.138^{*}$ & $0.154^{* *}$ & $0.123^{*}$ \\
\hline HEALTH2 & 0.015 & 0.007 & 0.008 & 0.036 & 0.013 & 0.013 & 0.017 \\
\hline CORR_TI? & & & & & & -0.037 & \\
\hline CORR_WB? & & & & & & & 0.826 \\
\hline \multicolumn{8}{|c|}{ INITIAL CONDITIONS } \\
\hline LOG(CAPITA90) & 0.857 & & & & & & \\
\hline FDEBT_93 & & -0.008 & & & & & \\
\hline HEALTH1_92 & & & -0.456 & & & & \\
\hline HEALTH2_92 & & & & $-0.087 *$ & & & \\
\hline EDU1_92 & & & & & 0.027 & & \\
\hline $\mathrm{R}^{2}$ & 0.73 & 0.73 & 0.73 & 0.74 & 0.73 & 0.73 & 0.74 \\
\hline $\mathrm{R}^{2}$ adj & 0.66 & 0.66 & 0.67 & 0.68 & 0.66 & 0.66 & 0.67 \\
\hline No. of countries & 22 & 21 & 22 & 22 & 22 & 22 & 22 \\
\hline OBS & 63 & 60 & 63 & 63 & 63 & 63 & 63 \\
\hline
\end{tabular}

Note: *, ** and $* * *$ indicate statistical significance at 10,5 and $1 \%$ levels.

Table 4d. Growth equations - initial conditions, 8-year averages GROWTH RATE OF GDP PER CAPITA (PPP, USD)

\begin{tabular}{|c|c|c|c|c|c|c|c|}
\hline X_OIL & $-0.097^{*}$ & $-0.100 *$ & $-0.104 *$ & $-0.100 *$ & $-0.107^{*}$ & $-0.104 *$ & $-0.115 * *$ \\
\hline X_OIL*@trend & $0.262 * * *$ & $0.263^{* * *}$ & $0.266^{* * *}$ & $0.259 * * *$ & $0.262 * * *$ & $0.263 * * *$ & $0.262^{* * *}$ \\
\hline CPI & -0.003 & -0.003 & -0.003 & -0.003 & -0.004 & -0.003 & -0.004 \\
\hline OPEN & 0.011 & 0.013 & 0.012 & 0.009 & 0.014 & 0.013 & 0.004 \\
\hline GOVC & -0.200 & -0.220 & -0.193 & -0.208 & -0.239 & -0.227 & -0.200 \\
\hline INV & $0.216^{*}$ & $0.218^{*}$ & $0.209 *$ & $0.203^{*}$ & $0.215^{*}$ & $0.211 *$ & $0.216^{*}$ \\
\hline INSTIT & 1.539 & 1.361 & 1.388 & 1.432 & 1.559 & 1.440 & 1.378 \\
\hline LABFOR & -0.247 & -0.180 & -0.185 & -0.101 & -0.239 & -0.203 & -0.115 \\
\hline REMIT & $0.394^{* *}$ & $0.421^{* *}$ & $0.418^{* *}$ & $0.410^{* *}$ & $0.413^{* *}$ & $0.410 * *$ & $0.443^{* *}$ \\
\hline EDU1 & $0.157^{*}$ & $0.150 *$ & $0.149 *$ & $0.150^{*}$ & 0.104 & $0.153^{*}$ & 0.121 \\
\hline HEALTH2 & 0.016 & 0.021 & 0.017 & 0.026 & 0.017 & 0.017 & 0.021 \\
\hline CORR_TI? & & & & & & -0.180 & \\
\hline CORR_WB? & & & & & & & 0.663 \\
\hline \multicolumn{8}{|c|}{ INITIAL CONDITIONS } \\
\hline LOG(CAPITA90) & -0.818 & & & & & & \\
\hline FDEBT_93 & & 0.006 & & & & & \\
\hline HEALTH1_92 & & & -0.112 & & & & \\
\hline HEALTH2_92 & & & & -0.027 & & & \\
\hline EDU1_92 & & & & & 0.067 & & \\
\hline $\mathrm{R}^{2}$ & 0.78 & 0.77 & 0.77 & 0.78 & 0.78 & 0.77 & 0.78 \\
\hline $\mathrm{R}^{2}$ adj & 0.69 & 0.68 & 0.69 & 0.69 & 0.69 & 0.69 & 0.70 \\
\hline No. of countries & 22 & 21 & 22 & 22 & 22 & 22 & 22 \\
\hline OBS & 44 & 42 & 44 & 44 & 44 & 44 & 44 \\
\hline
\end{tabular}

Note: ${ }^{*}, * *$ and $* * *$ indicate statistical significance at 10,5 and $1 \%$ levels. 


\section{Concluding Remarks}

In this study, we sought to uncover the extent to which Asian and European countries of the former Soviet Union are suffering from the Dutch Disease. The stylised facts showed that some of those countries are very dependent on the production and export of primary goods, in particular oil products. Despite the importance of oil production, we could not establish the presence of resource and spending effects because the relative prices declined in the last few years instead of rising, as would be expected in connection with Dutch Disease. Nevertheless, the share of manufacturing declined and the importance of the mining sector increased recently, along with a surge in real economic growth.

These are first indications showing that an increase in the price of oil does impact the real economies of the countries under study. Our analysis revealed that an increase in oil prices results in an appreciation of the nominal and real exchange rates, against both the dollar and the euro. But the pass-through from oil prices to exchange rate does take some time to materialise: we found that oil price increases feed into nominal and real appreciation with a lag of one or two years.

Finally, we addressed the question of whether relying excessively on natural resources impedes long-term growth or whether it has a positive effect on GDP. Our results based on growth regressions using 5-year and 8-year averages indicate that oil exports are linked positively with economic growth. Nevertheless, a high share of other primary goods - mainly agricultural products in total exports does not seem to promote growth. Our results also showed that oil exports had a negative effect on growth during the first stage of economic transition but made a positive contribution in the last years.

While data problems prevented us from determining whether there is a reallocation of labour between sectors due to high oil prices, our results with regard to the exchange rate and sources of economic growth are a clear sign of Dutch Disease: oil prices do cause nominal and real appreciation in the countries under investigation and, to the extent that non-oil manufacturing cannot stand the pressure, this will lead to deindustrialisation. Moreover, because economic growth is largely driven by oil exports in a number of countries studied in this paper, a future decline in oil prices or depletion of oil resources would probably jeopardize future GDP growth. 


\section{References}

Ahrend, R., D. De Rosa and W. Thompson. 2007. Russian Manufacturing and the Threat of 'Dutch Disease': A Comparison of Competitiveness Developments in Russian and Ukrainian Industry. OECD Economics Working Paper No. 540.

Barro, R. and X. Sala-i-Martin. 2004. Economic Growth. MIT Press.

Benigno, G. and C. Thoenissen. 2003. Equilibrium Exchange Rates and Capital and Supply Side Performance. Economic Journal 113 (486). 103-124.

Brůha, J. and J. Podpiera. 2007. Transition economy convergence in a twocountry model: implications for monetary integration. ECB Working Paper No. 740.

Chinn, M D. 1999. On the Won and other East Asian Currencies. International Journal of Finance \& Economics, 4(2), pp 113-127.

Civcir, I. 2003. The monetary models of the Turkish lira/dollar exchange rate: long-run relationships, short-run dynamics and forecasting. Paper presented at the EconMod2003 conference, July 3-5 2003, Istanbul. http://ecomod.net/conferences/ecomod2003/ecomod2003_papers/Civcir.pdf

Collier, P. and B. Goderis. 2007. Prospects for commodity exporters. Hunky Dory or Humpty Dumpty? World Economics 8(2). 1-16.

Corden, M. W. 1984. Booming sector and Dutch Disease economics: Survey and consolidation. Oxford Economic Papers 36(3). 359-380.

Coudert, V. 1999. Comment définir un taux de change d'équilibre pour les pays émergents? Economie Internationale. 77. 45-65.

Crespo-Cuaresma, J., J. Fidrmuc and R. MacDonald. 2005. The monetary approach to exchange rates in the CEECs. Economics of Transition. 13 (2). 395416.

Durlauf, S. N., P. Johnson, and J. R. Temple. 2004. Growth Econometrics. Vassar College Department of Economics Working Paper Series 61, Vassar College Department of Economics.

Égert, B. and C. S. Leonard. 2008. The Dutch Disease in Kazakhstan: An Empirical Investigation. Open Economies Review. 19. 147-165.

Égert, B., Halpern, L. and R. MacDonald. 2006. Equilibrium Exchange Rates in Transition Economies: Taking Stock of the Issues. Journal of Economic Survey 20(2), 253-324, 2006.

Égert, B., K. Lommatzsch and A. Lahrèche-Révil. 2006. Real Exchange Rates in Small Open OECD and Transition Economies: Comparing Apples with Oranges? Journal of Banking and Finance 30(12). 3393-3406.

El Shazly, MR. 1989. The oil-price effect on the dollar/pound rate of exchange. International Economic Journal. 3(3). 73-83.

Faruqee, H. 1995. Long-Run Determinants of the Real Exchange Rate: A StockFlow Perspective. IMF Staff Papers 42(1). 80-107. 
Goldberg, M D and R Frydman. 2001. Macroeconomic fundamentals and the $\mathrm{DM} / \$$ exchange rate: temporal instability and the monetary model. Oesterreichische Nationalbank Working Paper No. 50.

Groen, J J J. 2000. The monetary exchange rate model as a long-run phenomenon. Journal of International Economics, 52(2), pp 299-319.

Gylfason, T. 2001. Natural resources and economic growth: What is the connection? CESifo Working Paper No. 530.

Korhonen, I. and T. Juurikkala. 2007. Equilibrium exchange rates in oildependent countries, BOFIT Discussion Paper No. 8/2007.

Kronenberg, T. 2004. The curse of natural resources in the transition economies. Economics of Transition 12(3). 399-426.

Lopez, H., L. Molina and M. Bussolo, 2007, Remittances and the real exchange rate, World Bank Policy Research Paper No. 4213.

MacDonald, $R$ and M.P. Taylor. 1994. The monetary model of the exchange rate: long-run relationship, short-term dynamics and how to beat a random walk. Journal of International Money and Finance, 13(3), pp 276-290.

MacDonald, R. 1998a. What Determines Real Exchange Rates? The Long and Short of It. Journal of International Financial Markets. Institutions and Money 8(2). 117-153.

MacDonald, R. 1998b. What Do We Really Know About Real Exchange Rates? Oesterreichische Nationalbank Working Paper No. 28.

MacDonald, R. and L. Ricci. 2002. Purchasing Power Parity and New Trade Theory. IMF Working Paper No. 32.

Meese, R A and K. Rogoff. 1983. Empirical exchange rate models of the seventies: do they fit our of sample? Journal of International Economics, 14(1), pp 3-24.

Odedokun, M. 1997. The monetary approach to analyzing floating exchange rate behaviour in developing countries: evidence from Sub-saharian African Countries, 1986-1992. Journal of Development Economics, 52(2), pp 463-481.

Ollus, S.-E. and S. Barisitz. 2007. The Russian Non-Fuel Sector: Signs of Dutch Disease? Evidence from EU-25 Import Competition. BOFIT Online No. 2, Bank of Finland, BOFIT.

Oomes, N. and K. Kalcheva. 2007. Diagnosing Dutch Disease: Does Russia Have the Symptoms? BOFIT Discussion Paper No 6.

Papyrakis, E. and R. Gerlagh. 2004. The resource curse hypothesis and its transmission channels. Journal of Comparative Economics 32(1). 181-193.

Rahn, J. 2003. Bilateral Equilibrium Exchange Rates of the EU Accession Countries Against the Euro. BOFIT Discussion Paper No. 11.

Rapach, D E and M.E. Wohar. 2002. Testing the monetary model of the exchange rate determination: new evidence from a century of data. Journal of International Economics, 58, pp 359-385. 
Rapach, D E and M.E. Wohar. 2004. Testing the monetary model of exchange rate determination: a closer look at panels. Journal of International Money and Finance, 23, pp 867-895.

Sachs, J. and A. Warner. 1995. Natural resource abundance and economic growth. NBER Working Paper No. 5398.

Spilimbergo, A. 1999. Copper and the Chilean Economy: 1960-98. IMF Working Paper No 57. 